\title{
Jagten på en ADHD-diagnose Analyse af situationer og kontekster, hoor det bliver attraktivt at være psykisk syg
}

\section{Nichlas Permin Berger \& Katrine Schepelern Johansen}

\section{KORA}

nibe@kora.dk

Kompetencecenter for Dobbeltdiagnose i Region Hovedstadens Psykiatri katrine.schepelern.johansen@regionh.dk

Berger, Nichals Permin; Johansen, Katrine Schepelern (2016). ‘Jagten på en ADHDdiagnose: Analyse af situationer og kontekster, hvor det bliver attraktivt at være psykisk syg' i Tidsskrift for Forskning i Sygdom og Samfund, nr. 25, 129-154

Med udgangspunkt $i$ cases fra to feltstudier beskriver forfatterne, hvordan ADHD-diagnosen af flere forskellige grunde bliver attraktiv for professionelle og klienter med stofmisbrug $i$ Kriminalforsorgens institutioner og $i$ stofmisbrugsbehandlingsinstitutioner. Studierne fandt, at diagnosen bidrager med nye forklaringer til at forstå menneskers komplekse og vanskelige livsforløb og adfærdsmæssige problemstillinger. Det står centralt, at kriminel adfard - ofte den udadreagerende og voldelige - samt stofbrug opfattes som symptomer på at have ADHD. Som en integreret del af dagligdagssproget indgår diagnosen som ressource og aktiv komponent $i$ de indsattes identitetsarbejde, hvor stigma og afvigelser transformeres til sygdom, som kan behandles gennem brug af lovlig medicin fremfor illegale stoffer. ADHD-diagnosen giver de professionelle nogle særlige forståelser af de udfordringer, som de møder i deres klientrelaterede arbejde, da ADHD-diagnosen forskyder problematisk adfard fra spørgsmål om moral eller jura til spørgsmål om psykisk sygdom. Afslutningsvist relateres fundene til Nikolas Roses teorier om livets politik og biologisering, og hoordan skellet mellem normalitet og patologi udviskes. 
The pursuit of an ADHD diagnosis: Analysis of situations and contexts in which it becomes advantageous to be mentally ill

Based on the cases of two field studies, the authors describe how, for several reasons, the ADHD diagnosis can become an advantageous diagnosis for professionals and clients with substance abuse in institutions under the Prison and Probation Service and in substance abuse treatment facilities. The studies found that the diagnosis contributes new explanations for understanding individuals' complex and difficult life courses and behavioral issues. A crucial point is that criminal behavior - often of an outward reacting and violent kind - and drug use are seen as symptoms of having ADHD. As an integral part of everyday language, the diagnosis is drawn upon as a resource and an active component in prisoners' identity work, in which stigma and deviations are construed as disease that is treatable using legal drugs rather than illegal drugs. The ADHD diagnosis provides professionals with a specific understanding of the challenges they face in their client-related work, since the ADHD diagnosis displaces problematic behavior from being a question of morality or law to a question of mental illness. Finally, the findings are related to Nikolas Rose's theories about the politics of life and biologization and how the distinction between normality and pathology can be blurred.

\section{Indledning}

Diagnoser er formaliserede og institutionaliserede medicinske klassifikationer, der henviser til en bestemt patologi, og som klinikere anvender dagligt, når de skal forholde sig til en vifte af patienters symptomer. De psykiatriske diagnoser er beskrevet i diagnosesystemerne DSM-5 og ICD-10 (APA 2013 og WHO 1994). Diagnoser er dog også klassifikationsredskaber, som organiserer et kontinuum af menneskelige tilstande gennem at definere, hvilke der skal eller ikke skal regnes for sygdomme, og derved prioriterer diagnosen bestemte tilstande over andre (Bowker \& Star 1999). Diagnosen giver adgang til den sociale rolle som syg, og gennem en sådan symbolsk legitimering tildeler diagnosen mennesker retten til at kunne lide i samfundet, idet den gør det lettere at forklare, at man har en diagnose end at livet for eksempel er ondt eller meningsløst (Ekeland 2014).

Psykiatriske diagnoser kan, ifølge Petersen (2015), anskues som sociale kategorier, der er kulturelt forbundne med forestillinger om normalitet/afvigelse, skam, skyld og/eller stigma og forskellige grader af legitimitet og troværdighed. I forlængelse heraf er blikket for diagnosers sociale og relationelle dimension i front- 
medarbejderes daglige praksis centralt, fordi diagnoser kan handle om moralsk ansvar, give adgang til ressourcer, stigmatisere og legitimere bestemte former for adfærd, fungere som forklaring på komplekse og vanskelige livsforløb eller livssituationer samt transformere diffuse og modsatrettede oplevelser til sygdomme (Conrad 2007; Kleinman 1988; Jutel 2011).

Der er de senere år kommet en række studier, der kigger på psykiatriske diagnoser i et samfundsmæssigt perspektiv (f.eks. Brinkmann 2010; Brinkmann \& Petersen 2015; Petersen 2015; Rose 2007; Willig \& Østergaard 2005). Disse studier knytter udbredelsen af de psykiatriske diagnoser til overordnede samfundsmæssige processer. I denne artikel undersøger vi en bestemt diagnose i konkrete velfærdsinstitutioner. Dette er forskningsmæssigt relevant, fordi diagnoser er centrale for professionelles forståelse af borgeres individuelle problemer og dermed for professionelles praksis. Diagnoser både rammesætter og bliver rammesat af borgere og af professionelle (på medicinske såvel som andre fagområder). I samtidens diagnosekultur (Petersen 2015) kan psykiatriske diagnoser antageligt ikke længere blot anses at være stigmatiserende og begrænsende (Jutel 2011), men man må også se på, hvordan mennesker selv "tager diagnoser til sig«, og hvordan forskellige former for afvigelser og problematikker bliver individualiseret og italesat af omgivelserne som diagnostisk definerede problemer.

Både parallelt med og som en del af denne proces med et øget fokus på psykiatriske diagnoser er et biologisk paradigme de seneste årtier vokset frem, hvor mennesker i stigende omfang betragter hinanden og sig selv som neurologiske og biologiske individer (Rose 2007). I psykiatrien er tidligere tiders psykologiske og sociale sygdomsopfattelse på retur, og neuropsykiatrien med dens forståelse af psykisk sygdom, som knyttet til gener og processer i hjernens signalstoffer, er på fremmarch (Rose \& Abi-Rached 2013). Rose peger på, at brugen af medicin mod ADHD netop er et resultat af denne udvikling, og hvor vi tidligere medicinerede som led i regulering af personer med afvigende adfærd, tager individer i dag selv i højere grad initiativ til at indtage medicin for at regulere og tilpasse sig til dagligdagens udfordringer. Roses argument her er, at patienter selv er blevet centrale aktører i udviklingen af, det han benævner, 'livets politik' (Rose 2007), hvor normalitet/sundhed og patologi/sygdom ikke længere anskues som skarpt adskilte størrelser, og hvor biologi ikke længere er individets skæbne. Rose pointerer endvidere, at mennesker i dag anskues som aktive og ansvarlige borgere, der som potentielt syge konstant arbejder med at forbedre sig selv og sin egen sundhed.

Denne artikel handler om ADHD-diagnosen i konkrete institutionelle kontekster i Danmark, nemlig Kriminalforsorgen og stofmisbrugsbehandlingsinstitutio- 
ner - begge steder, hvor der i de senere år er kommet et betydeligt fokus på ADHDdiagnosen. Der er næppe tvivl om, at symptomerne knyttet til ADHD-diagno $\neg$ sen udgør betydelige problemer for de mennesker, som oplever dem. Samtidig har ADHD-diagnosen en stærk forklaringskraft på individuelle og sociale problemstillinger, idet den bidrager med andet og mere end det, der ligger inden for diskussionen af mere snævre kausale og patologiske sammenhænge (Berger 2015). De spørgsmål, som vi stiller i denne artikel, er, hvilke funktioner som diagnosen får i disse institutionelle kontekster, ud over at pege på relevant medicinsk behandling, hvad som sker med stofmisbrugeres og/eller kriminelles identiteter, når de får en ADHD-diagnose og hvad frontlinjemedarbejdere forstår ved diagnosen?

\section{To cases fra forskellige institutioner}

Det empiriske materiale, der trækkes på i denne artikel, er indsamlet af de to forfattere. Det materiale, som handler om mennesker med ADHD i Kriminalforsorgens institutioner, er indsamlet af Nichlas Permin Berger i forbindelse med hans ph.d.-projekt (Berger 2015). Undersøgelsens fokus var at se på, hvordan ADHD og kriminalitet diskursivt kobles sammen af voksne med ADHD-diagnose og af frontmedarbejdere i Kriminalforsorgen i den professionelle praksis. Dataindsamlingen blev gennemført som et institutionelt etnografisk feltarbejde i to af Kriminalforsorgens institutioner - et fængsel og i Kriminalforsorgen i Frihed. Der blev lavet observationer og gennemført interview med indsatte og tilsynsklienter samt gennemført fokusgruppeinterview med frontmedarbejdere fra begge institutioner. Undersøgelsen viste, at ADHD spillede en central rolle i samspillet mellem frontmedarbejdere og klienter/tilsynsklienter. Diagnosen blev både anvendt om mennesker med og uden diagnosen til at adressere en række forskelligartede individuelle egenskaber og problemstillinger, ligesom den virkede både meget tillokkende i en lang række situationer. ADHD-diagnosen var integreret i dagligdagssproget, og alle virkede fortrolige med den. På tidspunktet for feltarbejdet havde omtrent $10 \%$ af de indsatte i fængslet fået stillet en ADHD-diagnose.

Materialet om personalet på misbrugsinstitutioner og deres interesse i a få diagnosticeret ADHD hos stofmisbrugerne kommer fra en undersøgelse gennemført af Katrine Schepelern Johansen på flere danske misbrugsinstitutioner i perioden 2008-2012. Undersøgelsens primære fokus var implementering af behandlingen med lægeordineret heroin (se Johansen 2013). Dataindsamlingen inkluderede et omfattende feltarbejde på fire misbrugsinstitutioner, hvor der ud over behand- 
ling med lægeordineret heroin også foregik en række andre former for misbrugsbehandling. Undersøgelsen gav derfor mulighed for en række observationer og samtaler, der handlede om misbrugsbehandling mere generelt, herunder også personalets interesse i at få afdækket hvorvidt stofmisbrugerne havde en psykiatrisk diagnose - ikke mindst ADHD. Der er altså tale om en re-gennemgang af materiale oprindeligt indsamlet med et andet formål, hvor personalets interesse for en psykiatrisk diagnose hos klienter indskrevet $\mathrm{i}$ behandling er blevet identificeret og gjort til genstand for en analyse, der søger at forklare de lokale rationaler for denne interesse.

Selvom materialet i artiklen kommer fra to forskellige institutionelle kontekster, er der i den virkelige verden dog et betydeligt overlap af de to grupper af informanter. En stor del af brugerne indskrevet i stofmisbrugsbehandling har også begået kriminalitet (ofte for at finansiere deres misbrug) og har afsonet straffe af forskellig varighed. Flere er prøveløsladte fra fængslerne med vilkår om stofmisbrugsbehandling. Og en betydelig andel af de indsatte/klienter i de danske kriminalforsorgsinstitutioner har tillige et massivt brug af stoffer, ligesom der er mulighed for stofmisbrugsbehandling i alle danske fængsler.

\section{ADHD-diagnosen}

Psykiatriske diagnoser er syndromer, det vil sige, at der er tale om en samtidig forekomst af en række symptomer, hvis samtidige forekomst og alvorlighedsgrad kvalificerer til en konkret diagnose. De psykiatriske diagnoser er for langt de flestes vedkommende - herunder ADHD - også kendetegnet ved, at der ikke findes objektive kliniske test, for eksempel blodprøver, hjerneskanninger eller røntgenbilleder, som endeligt kan afgøre tilstedeværelsen af psykisk sygdom. Diagnosen stilles på baggrund af diagnostiske interviews med patienten selv, eventuelt informationer fra pårørende eller institutioner og i nogle sammenhænge observation af patienten over længere tid - for eksempel under indlæggelse på en psykiatrisk afdeling. Der findes to centrale diagnosemanualer - WHO's ICD-10 (1994) og den amerikanske psykiatriske organisations manual DSM-5 (APA 2013). Disse diagnosemanualer opstiller en række symptomer, der skal være til stede, for at en given diagnose kan stilles. Hvor der tidligere har været forholdsvis stor forskel på de to diagnosemanualer, er de med de seneste versioner kommet til at ligne hinanden mere og mere. I Danmark bruger vi officielt ICD-10 i forhold til de fleste diagnoser, 
men i nogle sammenhænge refereres der også til DSM-5. Dette gør sig blandt andet gældende i forhold til ADHD-diagnosen.

Historisk kan ADHD-diagnosen spores helt tilbage til det 19. Århundrede. Den blev tidligere betegnet som 'hyperkinesis', 'minimal brain damage' og 'attention deficit disorder' (Conrad 1975). ADHD anses i dag af den psykiatriske videnskab som den mest udbredte psykiske sygdom blandt børn, men inden for de seneste år er det blevet bredt anerkendt i psykiatrien, at ADHD ikke alene er knyttet til barndommen, men er en livsvarig lidelse. Dette blev understreget med den nyeste version af DSM (5), der introducerede diagnostiske kriterier for ADHD hos voksne (Prosser \& Reid 2013; Sundhedsstyrelsen 2015). Dette har givet anledning til, at psykiatrisk ADHD-forskning er begyndt at berette om 'underdiagnosticering', altså det fænomen at mange voksne går rundt med 'uopdaget ADHD' og følgelig ikke modtager relevant behandling herfor (Barkley 2010; Kooij et al. 2010). ADHDdiagnosen defineres i DSM som en biologisk dysfunktion, der resulterer i hyperaktivitet, uopmærksomhed og impulsiv adfærd i et sådan omfang, at der opstår problemer i hjemmet, på skolen eller på arbejdet. I en folkelig/populær forståelse af ADHD associeres diagnosen oftest med hyperaktiv adfærd, vanskeligheder med at skabe og vedligeholde relationer, ringe sociale færdigheder, vanskelig skolegang og lave karakterer samt højt uddannelsesfrafald.

ADHD har gennem mange årtier været genstand for kontroverser på grund af fraværet af definitive og klare forklaringer vedrørende begrebets ætiologi og interventionsstrategier, og der har også været fremført problematiseringer af diagnosens ontologiske validitet som sygdom (Moncrieff et al. 2011). Debatten er et udtryk for, at ADHD er kontekstualiseret i en række forskellige discipliner inden for de biomedicinske, psykologiske og sociologiske paradigmer. Det biomedicinske perspektiv peger på ADHD som primært forårsaget af en neurologisk dysfunktion, som skal løses med psykostimulerende medicin, og hvilket uden tvivl er den helt dominerende diskurs i akademisk såvel som professionel litteratur (Visser \& Jehan 2009), mens det psykologiske perspektiv baseres på teori om for eksempel eksekutive funktioner og kognition. I den sociologiske diskurs eksisterer ADHD ikke som en sand, objektiv sygdom (Ibid.: 128). Der er i denne diskurs forskellige perspektiver på ADHD, både hvor ADHD anskues som en socio-kulturel konstruktion og som en psykosocial sygdom. Endelig er der det bio-psykosociale perspektiv, hvor der inkluderes forskellige perspektiver på ætiologien og interventionen fra både bio-medicinske, psykologiske og sociologiske diskurser. ADHD fremstilles i dette perspektiv som resultatet af komplekse interaktioner 
mellem biologiske og sociale/kontekstuelle faktorer (Cooper 2008: 464), hvorfor effektive multidisciplinære interventioner foretrækkes inden for denne tilgang.

Antallet af ADHD-diagnoser er de seneste år massivt steget i Danmark (Jørgensen 2014). I år 2000 var der 0,40 personer pr. 1.000 indbyggere i medicinsk behandling for ADHD i den danske befolkning, mens der i 2013 var 17 gange flere - det vi sige cirka 7 personer pr. 1000 indbyggere. Denne stigning er særlig stor i de specifikke aldersgrupper børn og unge samt voksne i 20'erne og i 30'erne. I perioden 2000-2013 stiger andelen for aldersgruppen 10-14 år cirka 11 gange, for unge mellem 15-19 år cirka 41 gange og for voksne mellem 20 og 39 år over 100 gange. Den øgede brug af ADHD-medicin og af diagnosen har betydet, at koblingen mellem ADHD og andre problemområder er blevet genstand for stor opmærksomhed i den brede offentlighed. Det gælder ikke mindst i forhold til udviklingen af misbrug og kriminalitet, og specifikt er koblingen mellem ADHD, kriminalitet og misbrug blevet et 'hot topic' i danske såvel som i internationale medier, i politiske debatter, i den psykiatriske forskning og i nogen grad i kriminologien (Berger 2015: 136). For eksempel har ADHD-diagnosen vakt en betydelig interesse i fængsler og misbrugsinstitutioner gennem de seneste år. Disse to typer institutioner kendetegnes ved, at de håndterer problemstillinger, som har en betydelig moralsk dimension (Brinkmann 2014; Vehmas 2011). ADHD-diagnosen har en normativ dimension, idet den indeholder en lang række antagelser om, hvad for eksempel god adfærd er i skolen eksempelvis (Nielsen 2012:32; Prosser 2014). Samtidig giver ADHD-diagnosen - som vi vil vise i vores empiriske eksempler - mulighed for at forskubbe problemerne fra det moralske til det sygdomsmæssige.

En del af den forskning, der undersøger overordnede samfundsmæssige processer i relation til fremvæksten af diagnoser som ADHD, tolker fænomenet som udtryk for medikalisering og social kontrol eller en diagnosekultur, hvor almindelige livsproblemer kobles til medicinske kategorier og forbindes til medicinske interventioner. Her bliver ADHD en tillokkende løsning på problemer set ud fra frontmedarbejderes perspektiv. Men med Nikolas Rose er det også væsentligt at belyse, hvordan mennesker selv er aktive i denne proces. Hvorfor det er så attraktivt med en diagnose, kan givetvis variere i forhold til, hvem man spørger og i hvilken kontekst. I denne artikel undersøger vi diagnosens betydning i kontekster, hvori mennesker oplever at have været uden for det almindelige samfundsmæssige fællesskab og at have været anderledes. At have et blik på denne gruppe er vigtigt for at forstå den diagnostiske logik i dagens samfund. Ligeså væsentligt er det, når vi vender os mod borgere og professionelle i velfærdsinstitutioner og samspillet herimellem. Diagnosens sociale dynamik og fremvækst må altså an- 
skues som et samspil mellem på den ene side patienter og klienter, der i stigende grad anser diagnoser som meningsfulde og fordrende for personlig lettelse og forklaring, og på den anden side professionelle, som også finder, at diagnosen giver dem mening i deres daglige praksis. Således har vi et blik for både de, som får/ har/ønsker diagnosen, og et blik på de professionelle, der ønsker at diagnosticere (misbrugsbehandlere og ansatte i fængslet).

\section{Psykiatriske diagnoser i fængsler og misbrugsbehandling}

I dag dokumenterer forskningen utvetydigt, at en ADHD-diagnose for børn såvel som for voksne er en central risikofaktor for kriminalitet og stof- og alkoholmisbrug samt for overskridelse af sociale normer (Dalsgaard 2002; Christoffersen \& Hammen 2011; Maggs, Patrick \& Feinstein 2008). At der kan være en sammenhæng mellem en psykiatrisk diagnose og kriminalitet og misbrug har været kendt gennem mange år. Dog er den specifikke dynamik og retning stadig forskningsmæssig uafklaret (Gordon et al 2012), for eksempel formuleret som at en given diagnose er 'en selvstændig kriminogen faktor'. Det vil sige, at har man den pågældende diagnose, så er der en statistisk højere sandsynlighed for at blive dømt for kriminalitet (Poulsen et al. 2000). Forbindelsen mellem psykisk sygdom og misbrug er også velkendt (Mueser et al. 2003). Her går forbindelsen dog formentlig begge veje, således at psykisk sygdom øger sandsynligheden for udvikling af misbrug, og at misbrug øger sandsynligheden for udvikling af psykisk sygdom (Johansen 2009).

Traditionelt har en psykiatrisk diagnose fremfor andre været forbundet med kriminalitet og misbrug, og det er diagnosen 'dyssocial personlighedsstruktur', som har diagnosekoden F60.2 i ICD-10 (tidligere havde diagnosen navnet 'psykopat'). I den amerikanske DSM-5 svarer den til diagnosen 'anti-social personality disorder'). Diagnosen 'dyssocial personlighedsstruktur' har følgende diagnostiske kriterier: 1) grov ligegyldighed over for andres følelser, 2) manglende ansvarsfølelse og respekt for sociale normer og forpligtelser, 3) manglende evne til at fastholde forbindelser med andre, 4) lav frustrationstolerance og aggressionstærskel, 5) manglende evne til at føle skyld eller lade sig påvirke af erfaringer inklusiv straf og 6) bortforklarings- og udadprojektionstendens (WHO 1994: 138). Flere af disse symptomer er tæt knyttet til adfærd og handlinger, som normalt forbindes med 
kriminalitet og misbrug - f.eks. 'lav frustrationstolerance og lav aggressionstærskel' og 'manglende ansvarsfølelse og respekt for sociale normer og forpligtelser'. Der er således alene i kraft af de symptomer, som man bruger til at diagnosticere lidelsen med, et direkte link mellem lidelsen, kriminalitet og misbrug.

Forstyrrelser og forandringer af personlighedsstruktur og adfærd (som er diagnosegruppens formelle navn) regnes for at være blivende træk hos den enkelte, som har været til stede siden tidlig barndom og ikke kan behandles. De fleste interventioner sigter således imod at lære personer, der har en forstyrrelse af personlighedsstrukturen, at håndtere deres impulser og tendenser på socialt mere acceptable måder. En måde at forstå den meget store opmærksomhed og interesse for ADHD-diagnosen i fængsler og misbrugsbehandling er, at man med denne diagnose har fået et alternativ til personlighedsdiagnosen - et alternativ, der endda kan behandles effektivt og med medicin. Der er dermed tale om en diagnose, som af flere grunde fremstår langt mere attraktiv end den diagnose, der normalt har været at finde i denne kontekst.

\section{De professionelles perspektiv: Stofmisbrugsbehandling}

Gennem de sidste 10-15 år er der kommet stadig større opmærksomhed omkring, at mennesker med et stofmisbrug også kan have - og meget ofte vil have - en psykisk sygdom som angst, depression, psykose, PTSD eller ikke mindst ADHD. Et nyt dansk registerstudie anslår, at for mennesker med en psykisk sygdom er der en livstidsprævalens på ca. 30 \% for også at få et misbrug af enten stoffer eller alkohol (Toftdahl et al. 2015). En undersøgelse blandt mennesker i stofmisbrugsbehandling i Århus anslog i 2014, at mindst 40 \% også havde en psykisk lidelse (Frederiksen 2009). Et amerikansk studie finder, at 15-20 \% af voksne med et misbrug også har ADHD (Wilens 2006). Psykiatrifonden skriver om ADHD, at 55 \% af ADHD-patienter har en samtidig misbrugsproblematik (Psykiatrifonden 2007).

Denne øgede opmærksomhed på psykiatriske diagnoser blandt stofmisbrugere skyldes flere ting. Den er bland andet knyttet til, at man har fået mere viden om den samtidige forekomst af psykisk sygdom og stofmisbrug, dels fra udenlandske undersøgelser (f.eks. Blanchard 2000; Grant et al 2004) og dels efterhånden også fra danske projekter og undersøgelser (Frederiksen 2009; Flensborg-Madsen et al. 2009; Brasch et al. 2011; Toftdahl et al. 2015). En anden årsag er, at man generelt 
er blevet mere opmærksom på helbredsproblemer hos stofmisbrugere, både hvad angår det fysiske og psykiske helbred. Denne generelle opmærksomhed hænger blandt andet sammen med, at der i stadig øget omfang ansættes sundhedspersonale i misbrugsinstitutionerne ved siden af det socialpædagogiske personale, som tidligere dominerede misbrugsbehandlingen. En tredje årsag til den stigende opmærksomhed omkring psykisk sygdom hos stofmisbrugerne er indførslen af forskellige systematiske screeningsværktøjer (f.eks. KLs basisscreener for psykiske lidelser i misbrugsbehandlingen (Guldager og Hesse 2012)), der hænger sammen med den stadig øgede interesse for dokumentation og manualiserede behandlingsmetoder (se f.eks. Socialstyrelsen 2013, Møller \& Johansen (kommende)). Disse screeningsværktøjer kan ofte anvendes til også at screene for psykiske problemer/psykiatriske lidelser. Det bliver derfor mere tydeligt for personalet, at en forholdsvis stor del af de stofmisbrugere, som de har i behandling, har psykiske problemer ud over selve misbruget. Nedenfor præsenteres to eksempler på, hvordan den øgede opmærksomhed på ADHD viser sig i praksis.

Til en behandlingskonference på en misbrugsbehandlingsinstitution siger en kontaktperson om en bruger:

»Nu har Henrik været $i$ behandling her $i$ snart lang tid og har deltaget $i$ både individuelle samtaler og gruppe, og han siger, at det hjælper i forhold til hans brug af kokain. Men alligevel bliver han ved med at falde i. Sidst her da han fik penge i fredags, der har han været på kokain hele weekenden og er helt tømt - både økonomisk og mentalt - da jeg taler med ham mandag. Jeg begynder at tænke, om der er noget mere galt, om det er mere end bare almindelig afhængighed. Jeg har tænkt på at indstille ham til en samtale med Peter [den psykiater, der kommer to dage om måneden $i$ afdelingen] for at se, om han kan finde noget. Måske har han en depression og har brug for hjælp, eller måske er det noget $A D H D$, som han selv går og behandler på med kokainen."

En kontaktperson fortæller i en samtale om en bruger:

»Der er kommet meget mere ro på, efter at han er kommet $i$ ritalinbehandling. I stedet for at sidde og skyde sig med kokain, så er det ligesom om, at ritalinen har kunne give ham den effekt, som han provede at finde selv. Når man kigger tilbage $i$ hans journal, så kan man se, at han, allerede fra da han gik i skole, er beskrevet som en rigtig møgunge, der slet ikke kunne sidde stille og som altid lavede ballade og som tidligt kom i dårligt selskab, og man kan da ikke lade være med at tænke, at han da nok havde 
ADHD. Det er der jo mange af vores, der nok har, og hvis vi nu kan hjælpe dem med noget ordentlig medicin i stedet for det lort, som de går og tager selv."

Disse to eksempler illustrerer nogle af de sammenhænge, hvor ADHD-diagnosen bliver bragt i spil i stofmisbrugsbehandlingen i Danmark. I første eksempel ser vi, hvordan personalet efter et længere og ikke særligt vellykket behandlingsforløb begynder at overveje, om den egentlige årsag til klientens problem er noget andet. Der sker en forskydning fra det umiddelbare problem - stofmisbruget - til et andet og ifølge personalets opfattelse mere grundlæggende problem - den psykiske sygdom. Med denne forskydning sker der tre ting. For det første kommer der en anden type forklaring i spil. I stedet for at Henriks problem er et socialt problem - et problem, der skyldes en forkert adfærd, der er tillært i uhensigtsmæssige miljøer, så er der tale om et psykiatrisk defineret problem - et problem, der skyldes fejl i Henriks psyke, i hans signalstoffer eller i hans gener og dermed et neurobiologisk problem (Rose 2007). Det andet, der sker, er, at personalet får en logisk forklaring på Henriks stofmisbrug. Han har taget stoffer for at forsøge at behandle den psykiske sygdom, som han (måske) har, og som behandlingssystemet ikke har opdaget før nu. I litteraturen omkring psykisk sygdom og misbrug kaldes dette for 'selvmedicinering' (Gregg et al. 2007). Ordet selvmedicinering bruges også $i$ dag blandt for eksempel cannabisbrugere med ADHD-diagnose (Pedersen 2015) og blandt mange kriminelle med ADHD-diagnose, som afsoner i Kriminalforsorgens institutioner (Berger 2015). Dermed ændrer stofferne også karakter: fra at være illegale stoffer som brugerne tager for at blive påvirkede, nærmer det sig nu medicin, det vil sige legale stoffer, som man indtager for at få behandlet en sygdom (se også Johansen og Johansen 2014). Også stofbrugeren ændrer karakter: fra at være en person med en moralsk forkastelig praksis - at indtage forbudte stoffer for at opnå nydelse (Johansen 2015; Keane 2008) - til at være et individ med en neurobiologisk betinget sårbarhed, der kan kontrolleres ved hjælp af legitime, psykoaktive substanser. For det tredje sker der det, at personalet får en forklaring på, hvorfor de indtil videre ikke er lykkedes med deres behandling. Det er, fordi de har behandlet det forkerte problem - stofmisbruget fremfor den psykiske sygdom - og endda med en forkert metode - nemlig med social behandling frem for medicinsk behandling.

Sidst i den første case med Henrik introduceres også det forhold, at kokain og amfetamin kan have en meget specifik effekt på ADHD. Det er også det forhold, som er gennemgående i den anden case. Et af de mest almindelige præparater til behandling af ADHD er ritalin. Farmakologisk set minder ritalin og amfetamin 
meget om hinanden, og deres virkning er tilsvarende meget lig hinanden, hvilket også gælder kokain. Så hvad personalet taler om i de to cases er, at brugerne har behandlet deres ADHD med et illegalt præparat - kokain eller amfetamin, og at man nu i en behandlingsinstitution kan erstatte dette illegale præparat med et legalt præparat - ritalin (eller tilsvarende). I denne model trækker personalet på en behandlingsmodel, som de kender i forvejen - nemlig modellen, substitutionsbehandling (Ege 2004). Substitutionsbehandling var oprindelig kun tilgængeligt for mennesker, der var afhængige af opioider (dvs. heroin, morfin o.l.), og hvor man substituerede det forbudte stof med et legalt - ofte metadon og de senere år også buphrenorphin og lægeordineret heroin. Hermed fik man mulighed for at give brugerne det stof, som de oplevede at være afhængige af, under rolige og hygiejniske forhold, og brugerne fik ro til at koncentrere sig om deres problemer, fordi de ikke længere var præget af abstinenser. Tidligere har misbrugsbehandlingen ikke på samme måde haft mulighed for substitutionsbehandling af andre former for afhængighed, men introduktionen af ritalin og andre centralstimulerende præparater har givet mulighed for at udvide substitutionsbehandlingsmodellen til også at omfatte stimulanser som kokain og amfetamin. I dag kan man dog endnu ikke udskrive ritalin, fordi nogen er afhængige af stimulerende stoffer - det kræver en ADHD-diagnose, før dette er en mulighed. Som beskrevet ovenfor i afsnittet om psykiatriske diagnoser i fængsler og misbrugsbehandling stammer en del af attraktionen ved ADHD-diagnosen formentlig fra netop dette forhold: at den peger på en mulig medicinsk behandling.

Endelig viser de to eksempler, hvordan ADHD-diagnosen er blevet en fuldstændig integreret del af retorikken på misbrugscentrene, hvor der hverken stilles spørgsmålstegn ved dens eksistens eller applikation på stofbrugere, samt at den medicinske behandling uproblematisk integreres med de øvrige behandlingstiltag på centrene. Hvor man tidligere kunne finde modstand mod psykiatriske diagnoser blandt det social-faglige personale på behandlingsinstitutionerne, synes denne modstand at være aftaget og erstattet af en oplevelse af, at den psykiatriske diagnose bidrager konstruktivt til misbrugsbehandlingen.

\section{De professionelles perspektiv: Kriminalforsorgen}

Antallet af ADHD-diagnoser og forbruget af ADHD-medicin har som tidligere nævnt været i massiv vækst i Danmark og i mange vestlige lande gennem de senere år. Dette gælder i særlig grad blandt Kriminalforsorgens klientel, der i stigende 
grad er blevet sat i forbindelse med ADHD. Andelen af ADHD-diagnosticerede under Kriminalforsorgen er i dag langt højere end i befolkningen generelt. For det første afspejler den massive stigning af ADHD-diagnoser blandt Kriminalforsorgens klientel, at ADHD-diagnosen kan stilles under fængselsafsoning af de tilknyttede psykiatere i fængslerne. For det andet skyldes det en udbedt opfattelse af, at en øget indsats på ADHD-området med en øget behandlingsindsats kombineret med en stigning i de professionelles vidensniveau om ADHD kan understøtte afsoningsforløbene med kriminalitetsforbyggende gevinster til følge (Young et al. 2011). Logikken understøttes af, at indsatte i forvejen er en stærkt udsat gruppe med en stor overrepræsentation af psykiske såvel som materielle og sociale problemer såsom stof- og alkoholmisbrug, lav uddannelsesbaggrund og ringe familiebaggrund (Kyvsgaard 1989). For det tredje er det muliggjort af, at voksne med DSM-5 nu også kan kvalificeres til en ADHD-diagnose. For det fjerde kan der være forskellige fordele ved, at den indsatte får en ADHD-diagnose og bliver medicineret, både for den indsatte selv såvel som for de professionelle. Mange indsatte/klienter og professionelle i Kriminalforsorgen beskriver og associerer de indsattes adfærd og bestemte typer af sociale problemer som udtryk for ADHD. Det mest markante eksempel herpå er stofmisbrug, hvilket forskningen da også peger på, er karakteristisk for mange kriminelle med en ADHD-diagnose. Derved får klienter såvel som professionelle en tilsyneladende sikker indikation på, at man lider af ADHD, og en sådan indikation er både intuitiv og let forståelig og har samtidig en række implikationer for samspillet mellem indsatte/klienter og professionelle i Kriminalforsorgen.

Berger (2015) viser, hvordan ADHD som et socialt og kulturelt fænomen har en særlig status, legitimitet og værdi mellem indsatte/klienter og frontmedarbejdere i Kriminalforsorgen, og at frontmedarbejderne ofte forholder sig til ADHDdiagnosen i deres daglige arbejde. Gennem de professionelles daglige sociale interaktioner med klienterne får diagnosen nogle helt situationsspecifikke betydninger. Frontmedarbejderne, som oftest er fængselsmedarbejdere, sygeplejersker, skolelærere og socialrådgivere, har direkte og daglig kontakt med klienterne og er generelt kritiske over for ADHD-diagnosen, der generelt beskrives som valid. ADHD beskrives i vidt omfang med et neurobiologisk ordbrug (Rose 2007) som en lidelse, der er forankret i hjernen og som både kan og skal behandles medicinsk. De professionelle fortæller, at de oplever at have en konstant udfordring med at skelne mellem dem, som 'virkelig har ADHD', og dem, som blot påstår, at de har en ADHD-lidelse. De professionelle fortæller, at de ofte møder klienter, som er meget interesserede $i$ at fremhæve en mulig eller aktuel ADHD-relateret proble- 
matik. Efterspørgslen fra indsatte/klienter karakteriseres af frontpersonalet som 'nemme' undskyldninger i et forsøg på at opnå former for legitimering af mere eller mindre tilladt eller accepteret adfærd, mens efterspørgslen efter diagnosen i enkelte tilfælde ikke beskrives strategisk, men mere som den indsattes/klientens forsøg på at få hjælp eller støtte til sin dagligdag.

Samtidig fortæller frontmedarbejderne, at de ikke finder det særligt relevant at forholde sig til diagnosen, da den efter deres opfattelse ikke gør nogen betydelig forskel for deres praksis. Ikke desto mindre viser det sig gennem deres beskrivelser af egen praksis, at den alligevel har en vis betydning i dagligdagen. Når der er identificeret en person med et aktivt stofmisbrug, særligt når visse stoffer kombineres, er det ifølge de professionelle en meget sikker indikation på, at denne person har ADHD. Følgende uddrag fra et fokusgruppeinterview med forskellige typer af professionelle i fængslet er et typisk eksempel på, hvilken betydning ADHD tilskrives:

»Og hvis man så allerede under indsættelsessamtalen siger, at jeg har også ADHD eller er ved at blive udredt, så går fangen allerede der ind og siger, at jeg forventer særbehandling på et eller andet punkt. Desværre går det ud over dem, der rent faktisk fejler noget, fordi der er en tendens til at udnytte det. Men jeg har personligt oplevet en fange, der kom ud af sit misbrug ved at blive udredt for ADHD. Så bruger de jo både amfetamin til medicin og efterfølgende hash for at kunne sove. Så hvis de bliver udredt korrekt og fejler noget, så ser du sgu, at det bliver en helt anden fange, du kommer i nærheden af. Det er jo en kæmpe fordel. Det er så bare træls, at der er blevet en tendens til, at nu har vi alle sammen $A D H D$, fordi så er det hele meget bedre, og så får vi særbehandling.« (Fokusgruppeinterview i et åbent fængsel)

Såvel de indsatte som de professionelle anvender begrebet 'selvmedicinering' om indtagelse af illegale stoffer såsom amfetamin, hash og kokain, og de anser en sådan afhængighed som en klar indikation på ADHD (sådan som vi også tidligere så det i misbrugsbehandlingsinstitutioner). Generelt beskriver frontmedarbejderne en stigende tendens til, at indsatte i fængslet i dag til forskel fra få år tilbage tydeligt giver udtryk for, at de ønsker individuel særbehandling og fremhæver, at de har ADHD og derfor har brug for medicin. Eksemplet viser også, at en succes med medicinering i form af minimering af urolig adfærd og gennem at erstatte et stofmisbrug med ulovlige stoffer med medicin bekræfter, at den indsatte har et 'dybereliggende' problem i form af en ADHD-lidelse - igen som vi også så det i misbrugsbehandlingen. Dermed bekræftes diagnosens validitet. Generelt beskri- 
ver de professionelle de indsatte, som har eller mistænkes for at lide af ADHD, som adfærdsforstyrrede, flagrende, desorienterede, svære at motivere og med ringe sociale kompetencer/situationsfornem $\neg$ melse. De beskrives også som egoistiske, asociale, hyperaktive med overskud af energi (kravler på væggene/kører rundt på stolen) og forbindes i vid udstrækning med stofmisbrug og kriminalitet.

For de professionelle er der således ikke nogen tvivl om, at ADHD, som en lidelse er helt reel. ADHD beskrives som en kronisk lidelse i hjernen, og i de professionelles daglige praksis i både fængslet og i Kriminalforsorgen i Frihed opleves det som en stor udfordring at skelne mellem, hvornår en indsat virkelig har ADHD, eller hvornår vedkommende blot benytter diagnosen aktivt til at opnå noget, eksempelvis fritagelse for arbejde eller i mange tilfælde for at få stillet et attraktivt stof (ritalin) til rådighed.

\section{En fælles diskursiv ressource}

I de foregående afsnit om professionelle på henholdsvis misbrugsbehandlingsinstitutioner og i Kriminalforsorgen viste vi, at der er et betydeligt overlap mellem forståelser blandt de professionelle. Begge steder beskrives misbrug af stoffer som selvmedicinering på baggrund af en psykisk lidelse, der begge steder også beskrives som 'bagvedliggende' og dermed også mere 'ægte' end selve misbruget, der kun er en afledning af lidelsen. I begge personalegrupper oplever man, at man har fået et bedre og mere nuanceret syn på misbrugets årsag, end man har haft tidligere, og at man har fået udvidet sit behandlingsrepertoire med nye tilgange og nye præparater. Som Berger har konkluderet andetsteds, så bliver "... denne biologiske forklaring [...] herved en diskursiv ressource for de professionelle til at forholde sig til, hvordan mennesker med en ADHD-problematik skal hjælpes" (Berger 2015: 199).

\section{De indsattes perspektiv}

På tidspunktet for interviewene med de kriminelle fik de tilsyn af Kriminalforsorgen i form af periodiske besøg af socialrådgivere i eget hjem. Karakteristisk for de kriminelles fortællinger var, at ADHD aldrig blev benyttet til at forklare enkeltstående kriminelle handlinger. Derimod blev ADHD aktivt og uden interviewerens opfordring brugt til at etablere en generel forklaringsramme for deres 
på mange måde afvigende fortid præget af kriminalitet, stofmisbrug og oplevelser af at føle sig udenfor. De fleste havde fået diagnosen som voksne, og ADHD indgår på mange måder i deres fortællinger, så diagnosen bliver gjort til deres personlige skæbne. De næste to cases er tidligere benyttet i Berger (2015). I narrativet 'ADHD som skæbne' bebrejdes omgivelserne - i særdeleshed skolen, men også myndighederne - bredt for, at de ikke har identificeret ADHD-lidelsen tidligere med henvisning til, at de gerne ville have undværet dele af det hårde liv, som de har levet. Den første case handler om John, som er blevet diagnosticeret i 30'erne. Han har tidligere handlet meget med stoffer fra sin egen lejlighed, og han har siddet mange gange i fængsel.

Interviewer: Kan du prøve at fortælle, hoad ADHD betyder for dig?

John: Ja, det kan jeg godt. Jeg synes, det gør, at jeg fär ro i mit liv, og at de ligesom har erkendt, at de godt kan se, at jeg havde det. Fordi det var svært, at de ikke ville se det?

Interviewer: Altså Kriminalforsorgen?

John: Ja også det, folk rundt om mig kunne jo godt se, at der var fart på mig. Og de syntes jo, at det var noget værre noget, at der ikke var nogen, der gik og sagde: "Nu må du sgu vågne op". Indtil [navnet på hans hustru] sagde: "Nu gider jeg ikke mere" så ah, så sagde jeg: "Så tag med over, jeg skal tale med [overlægen på sygehusafdelingen], da han var der, ik'?". Så sagde hun: "Nu må de fandme høre på, hvad jeg også siger, det er altså mig, der lever sammen med dig, og din familie ved det, ik'?".

I Johns fortælling er det tydeligt, at han - qua hans kriminelle fortid - får mulighed for at forklare tidligere begivenheder og oplevelser. Johns udsagn kan tolkes som om, at han antager, at der er en fælles genkendelig forståelseshorisont i forhold til ADHD-diagnosens betydning på disse punkter, og at han derved forventer, at fortællingen vil blive accepteret af intervieweren.

I materialet er der mange eksempler på, at diagnosen både er kærkommen og en befrielse fra skyld. Den er også i vid udstrækning en definitiv bekræftelse på, at der virkelig var og er noget galt med den kriminelle. Psykiateren har med diagnosen givet John en anvisning til og mulighed for at omdefinere fortællingen om sig selv og altså en rationel og legitim sygdomsforklaring på et vanskeligt, forvirret og stigmatiseret liv som kriminel og stofmisbruger. I eksemplet her og i de øvrige kriminelles fortællinger om ADHD-diagnosen accepteres den som en 
lidelse, der er forankret i hjernen. Samtidig er der ingen af de interviewede, som stiller spørgsmålstegn ved ADHD-diagnosen i forhold til dens specifikke relevans i forhold til, at de selv har fået diagnosen.

Det anden case handler om fortællingen om sig selv som et livslangt offer for velfærdssystemet, og her fremhæves især systemets utilstrækkelighed. Et gennemgående kritikpunkt er, at klienterne beklager og kritiserer systemet for, at ADHD ikke blev opdaget tidligere i deres liv. Denne 'narrative genre' er velkendt blandt sociale velfærdsklienters livshistorier (Järvinen 1998), som handler om, at systemet har fejlet. Klienterne påberåber sig her en 'offerrolle' i mødet med intervieweren. Dette kan tolkes som en måde, hvorpå afvigende adfærd, f.eks. kriminalitet, stofmisbrug og vanskeligheder ved at leve op til samfundsmæssige normer og værdier, bidrager til etablere en nærhed eller samhørighed til intervieweren. Det fornemmes også, at klienterne utvetydigt forventede, at interviewer ville acceptere deres fremstilling af ADHD-diagnosen som en gyldig og troværdig forklaringsramme.

Claus, som er et sted i 20'erne, fortæller om hans oplevelse af at gå i skole og af skolelærerne, og man kan se brugen af ADHD-diagnosen som en måde, hvorpå skyld og socialt ansvar problematiseres og i en vis udstrækning nedtones.

Interviewer: Og hoor gammel er du nu?

Claus: Jeg er [et sted i tyverne], eller det bliver jeg i denne måned. Men jeg kunne godt se det, da jeg fik det ned på papir, var inde og læse om det og kiggede tilbage på, hvordan mine handlemønstre og sådan noget har været, så kan jeg ikke forstå hvorfor det ikke er blevet opdaget før. Jeg gik til skolepsykolog, da jeg gik i børnehaveklasse, fordi jeg slåssede meget og bankede de andre. Dengang var det ikke så udbredt, man kendte ikke noget til det. Så hun sagde bare at det var på grund af mine forældres skilsmisse. Så røg jeg ud af skolen og kom i misbrug og sådan noget, og så blev der aldrig taget hul på det.

Interviewer: $\mathrm{Og}$ det var allerede i folkeskolen, du selv blev opmærksom $p a ̊$, at der var et eller andet?

Claus: Ja, allerede dengang havde jeg jo min adfard. Det er bare først så lang tid senere, at der er blevet puttet ord på det. Jeg kan godt se, når jeg kigger tilbage, så fatter jeg ikke, hvorfor de ikke har opdaget det. Hun er psykolog, så hvorfor har hun ikke opdaget det eller tænkt det som en tanke. Men det havde hun ikke. 
Det er tydeligt, at Claus bebrejder de professionelle i hans barndom for, at de ikke gjorde mere for ham, og han præciserer dette yderligere ved at sige, at de burde have opdaget 'det' - altså hans ADHD-lidelse. Han sammenligner med skolen i dag og siger, at havde det været i dag, så ville det være blevet opdaget; han ville have undgået mange negative oplevelser i sit liv og nævner mobning og dårlig skolegang. I materialet bliver ikke kun skolen bebrejdet for ikke at have opdaget ADHD lidelsen, men også forældrene og 'systemet'. I nedenstående citat fortæller Jesper, hvordan det gik til, da han for tre-fire år siden fik diagnosen som voksen, da han var i midten af 20'erne.

Interviewer: Hvordan kom det i stand?

Jesper: Det var, fordi jeg kom ned til [navn på psykiater] og fik konstateret det dernede. Der har jeg gået nede for nogle år siden i forvejen på grund af, at jeg havde det skidt med selvmordstanker og alt muligt. Så droppede jeg ud af den behandling, og så fik jeg det skidt igen. Så kom jeg derned, og så fandt han ud af, at jeg havde det ADHD og så noget psykisk forstyrrelse også. Siden jeg fik hjælp nede ved ham, der er det kun gået fremad. Jeg har ikke taget stoffer eller noget siden.

Interviewer: Så det er hoor mange år siden?

Jesper: Det er cirka to-tre år siden. Jeg har holdt mig fra stoffer siden.

Interviewer: Er du så medicineret i forhold til ADHD?

Jesper: Ja, jeg er så. Det får jeg medicin for hver dag.

Interviewer: Så det var egentlig den vej rundt, at der var nogle andre ting, der var presserende, at du havde det skidt. At du så den vej igennem...

Jesper: Ja, men jeg tog stoffer, fordi når jeg tog stoffer, så fik jeg det roligt og kunne slappe af, og havde det godt med mig selv og alt muligt. Det var ligesom om, at man ikke havde det sådan, når man var ved at løbe tør for stoffer. Så blev jeg helt angst og skulle bare ud og lave alt muligt for at have penge til det.

Interviewer: Ja, for at finansiere det? 
Jesper: Ja. Det var meget af det kriminalitet, jeg lavede, det var på grund af det. Simpelthen. Der skal også noget til, når man skal have det til arbejde og alt muligt.

Jesper er i dag medicineret for ADHD og har været det de seneste år. I uddraget bliver ADHD her en moralsk kategori, hvor klienten, som tidligere har været $\mathrm{i}$ fængsel, bruger en medicinsk legitimering af sit tidligere stofmisbrug gennem indirekte henvisning til 'selvmedicinering'. På denne vis foretager han en symbolsk grænsedragning (Lamont \& Molnár 2002), hvor han - gennem reference til ADHD - differentierer sig fra en 'stofmisbruger' og fra en 'kriminel', som begge typisk er blevet opfattet som moralsk inferiøre og stigmatiserende identitetskategorier. Han fortæller, at han tidligere tog mange stoffer for at håndtere, at han havde det skidt på grund af dét, som han senere fik bekræftet - nemlig at der var tale om ADHD og 'noget psykisk forstyrrelse'. Virkningen af de illegale stoffer bekræfter sammen med medicinens virkning, at han virkelig fejler noget $i$ hjernen. Koblingen til kriminalitet ligger i dét, at Jesper fandt det nødvendigt at sørge for, at han selv havde det godt og var i balance. Derfor blev han nødt til at lave kriminalitet for at få penge hertil, hvilket bliver præsenteret som noget helt legitimt og inden for en forventet kulturelt genkendelig forstålseshorisont, hvor han antager at være helt overvejende enig med interviewer om betydningen af ADHD-diagnosen.

\section{Afsluttende diskussion: ADHD som attraktiv diagnose}

Vi har vist, at ADHD-diagnosen indgår som en legitim diskursiv ressource for klienter såvel som for de professionelle i Kriminalforsorgen og i stofmisbrugsbehandlingen i modsætning til tidligere, hvor psykiatriske diagnoser ikke var et område, som man arbejdede med i disse institutionelle sammenhænge. I analysen af datamaterialet var det tydeligt, at ADHD har fået karakter af en dagligdagskategori, som alle havde et forhold til og kendte. I analysen af vores empiriske materiale fandt vi, at beskrivelserne af ADHD-diagnosen i vid udstrækning var enslydende mellem de professionelle og klienterne og på tværs af begge institutionelle kontekster. Bergers feltarbejde og materiale viser, at ADHD-diagnosen var blevet relativt udbredt i fængselsvæsenet, således at de fleste indsatte enten havde ADHD eller som minimum symptomer herpå. Tilsvarende finder vi hos personalet i misbrugsbehandlingen, at de anvender ADHD-diagnosen i deres daglige praksis. ADHD-diagnosens ægthed betvivles ikke, og det er en udbredt 
fortælling, at misbrugernes og de kriminelles liv kunne have været gået væsentligt bedre, hvis blot ADHD-lidelsen var blevet opdaget tidligere.

Eksemplerne viser også, at omsætningen af symptomer til en konkret diagnose foregår i en løbende udveksling og forhandling mellem patienterne og de forskellige professionelle, som de er i kontakt med i kriminalforsorgen og stofmisbrugsbehandlingen. Diagnoserne har dermed en relationel dimension, og dermed viser artiklen også relevansen af et interpersonelt perspektiv på ADHD (Nielsen 2012:37) og af at undersøge den dynamik, der gør ADHD-diagnosen så attraktiv, når ADHD-diagnosen spiller sammen med og reflekterer den aktuelle samfundsmæssige og kulturelle samtidskontekst.

Casene viser, at ADHD-diagnosen er en attraktiv og anerkendt forklaringsramme og diskursiv ressource for at forstå marginaliserede og problemfyldte liv, og det er muligt at trække på diagnosen i mange sammenhænge og for klienternes vedkommende også til at forklare og legitimere sine handlinger eller livssituation og derved problematisere spørgsmål om skyld og ansvar.

De medicinske begrundelser angående brug af stoffer og uhensigtsmæssig adfærd - mangel på visse signalstoffer i hjernen - er også helt almene i de to institutioner, som vi har undersøgt. Trods det forhold, at der næppe er forskningsmæssigt belæg for, at hverken kokain eller cannabis skulle være særlig godt til at behandle ADHD, var denne forklaring udbredt, og klienterne oplevede da også at få det bedre ved brug af disse stoffer. Gennem referencen til ADHD blev klienternes stofmisbrug indsat i en ramme, hvor de betoner den psykiske sygdom som afgørende for det fortsatte misbrug, og fordi det var så svært at komme ud af det ved egen hjælp. Samtidig introduceres den medicinske behandling af ADHD som en attraktiv løsning og som et bud på en legal substitution af et illegalt stof.

Der bliver i materialet generelt benyttet mange symbolske grænser, som har til formål at tydeliggøre, hvor grænserne ligger i forhold til karakteren af bestemte fænomener. Med ADHD får man en ressource, som muliggør nye former for symbolske grænser ved for eksempel at minimere omfanget af stigma knyttet til kategorierne 'stofmisbruger' eller 'kriminel'. Flere klienter beskrev, hvordan diagnosen havde fået mange ting til at falde på plads og gav mening til problemfyldte livsforløb, hvor for eksempel vanskeligheder i skolen, stofbrug eller kriminelle handlinger ikke længere bliver forstået moralsk problematiske, men som symptomer på ADHD. Diagnosen synes på denne vis - som diskursive ressourcer - at være til rådighed for klienterne og patienterne såvel som de professionelle som en kulturelt accepteret fortolkning af bestemte typer af problemer. 
Diagnosen er altså ikke blot en neutral kategori, som lægen stiller nogle mennesker for at hjælpe. Derimod er diagnosen også en kategori, som indsatte og stofbrugere samt personale i fængsler og misbrugsbehandlingsinstitutioner tilsyneladende relativt let kan bruge i eget og andres livsforløb til at identificere årsager såvel som løsninger på en række vanskeligheder i forhold til kriminalitet, misbrug, skolegang og arbejde. Vi har vist, at ADHD-diagnosen spiller en central rolle i klienters selvfortællinger, og at disse ligner de professionelles forståelser af diagnosen og de hertil knyttede vanskeligheder. Tor-Johan Ekeland (2014) skriver, at identitetsprojekter i vores samtidskultur er blevet så komplicerede, at diagnosen giver den enkelte en "symbolsk asyl" eller et fristed:

"for å sleppe unna det normale livet med alle dei krav og forventningar ein likevel ikkje trur det er mogleg å leve opp til (Ekeland, 2009). Å vere sjuk kan opplevast som eit betre identitetsprosjekt enn å vere mislukka" (Ekeland 2014:721)

Diagnosen giver, skriver Ekeland, et navn for det meningsløse eller det komplicerede mellem mennesker, fordi diagnosen sætter ord på det vanskelige, og samtidig er diagnoser attraktive, fordi de kan fritage for skyld og ansvar og holde en udenfor (ibid.). Der er mange eksempler i materialet på, at klienterne og patienterne taler ukritisk og indforstået om ADHD-diagnosen.

Det er et gennemgående træk i både de professionelles og klienternes fortællinger om ADHD, at de næsten udelukkende bruger en neurobiologisk diskurs (Rose 2007), hvor kriminelle stofmisbrugeres handlinger i vidt omfang udlægges som konsekvenser af neurokemiske processer i hjernen, som er i ubalance (Berger 2015). Datamaterialet indeholder kun en smule, hvor ADHD udlægges som noget mangelfuld socialisering og dårlig opdragelse, som tidligere har været dominerende forklaringer på den adfærd, der i dag bliver karakteriseret som symptomer på ADHD. Rose (2010) benytter begrebet 'the susceptible individual' for en ny type sårbart menneske, som ikke fx begår kriminalitet eller er afhængig af stoffer som resultat af en sygdom i personen eller af manglende vilje, men som konsekvens af en sygdom i hjernen.

Mange psykiatriske diagnoser er ofte blevet opfattet og erfaret som stigmatiserende (Rasmussen og Johansen 2013). Materialet i nærværende artikel viser, at dette forhold ikke er entydigt, og at der findes bestemte institutionelle sammenhænge, hvor psykiatriske diagnoser - her ADHD - opfattes som mere attraktive and alternativet. Rose forklarer, at hvor diagnoser tidligere overvejende blev anset for stigmatiserende og måtte betragtes som ikke-ønskværdige, har flere psykiatri- 
ske diagnoser i dag skiftet karakter og blevet udtryk for en normalitet, hvor alle mennesker potentielt er syge og sårbare, og hvor det er vigtigt at få stillet diagnosen hurtigt, så man kan komme i gang med en behandling (Rose 2007). Psykiatriske diagnoser, som for eksempel depression og ADHD, er blevet almene og ret udbredte, og de er kommet til at spille en væsentlig rolle for menneskers sociale identitet og dannelsen af denne. Mennesker, som har levet et liv som outsidere eller marginaliserede, får gennem diagnosen en ny og tillokkende forklaring på deres liv, som i den grad i dag - og til forskel fra tidligere - er acceptabel og almen $i$ et samfund, som kan karakteriseres ved en 'diagnosekultur', hvor diagnoser i vid udstrækning skaber identitet (Brinkmann 2014; Brinkmann \& Petersen 2015).

Fra institutionernes perspektiv er diagnosen især attraktiv, fordi der på baggrund af den introduceres en lang række sofistikerede 'styringsværkstøjer' og interventioner i form af f.eks. kognitive adfærdsprogrammer og medicin, hvorigennem disse sårbare individer forsynes med indsigter, viden, teknikker og evner til selv-styring, som, ifølge Rose, tildeles individer, for at de kan leve et liv i viden om sine sårbarheder, så de kan tage ansvar for at undgå handlinger og situationer, som kan aktivere disse sårbarheder. Gennem en neurologisk forståelse af mennesket (Rose 2010) bliver ADHD i casene karakteriseret som forklaringer på klienter og patienters mentale tilstand og sårbarhed. ADHD har ifølge informanterne resulteret i komplekse og vanskelige livsforløb, og det præsenteres som en ubetinget nødvendighed kontinuerligt at arbejde på at håndtere denne tilstand og sårbarhed. Casene viser, at ADHD-diagnosens centrale rolle ikke alene er udtryk for de professionelles interesse eller kontrol, og at diagnosen forbindes med nogle forklaringer, som alle i en eller anden udstrækning abonnerer på, finder legitime og anerkender som relevante.

\section{Referencer}

APA (2013). Diagnostic and Statistical Manual of Mental Disorders, American

Psychiatric Association. 5. ed., American Psychiatric Publishing Group, Washington: USA.

Barkley, R.A. (2010). Attention deficit hyperactivity disorder in adults - The latest assess ment and treatment strategies, Jones \& Bartlett Publishers, London: UK.

Berger, N.P. (2015). ADHD som socialt og kulturelt fænomen. En analyse af, hvordan diagnosticerede dømte voksne og frontmedarbejdere med relation til Kriminalforsorgen tilskriver ADHD-diagnosen betydning. Ph.d.-afhandling. Aalborg: Aalborg Uni versitetsforlag. 
Blanchard, J. J. (2000). The co-occurrence of substance use in other mental disorders: Editor's introduction. Clinical Psychological Review, 20, 145-8. https://doi.org/10.1016/S0272-7358(99)00024-0

Bowker, G.C. \& Star, S.L. (1999). Sorting things out: Classification and its consequences.New Baskerville, The MIT Press.

Brasch, B. Christensen, I. Henriksen, J. Larsen, L., Sørensen, A. \& Zeuthen, C.(2011). Vidensbase - indsatsen for mennesker med sindslidelse og misbrug. Køben havn: Socialt Udviklingscenter SUS.

Brinkmann, S. 2010, Patologiseringstesen: Diagnoser og patologier før og nu. I: (2010). Det diagnosticerede liv. Sygdom uden grænser, ed. S. Brinkmann, Forlaget Klim, Århus, 15-31.

Brinkmann, S. (2014). Psychiatric diagnoses as semiotic mediators: The case of ADHD, Nordic Psychology, Vol. 66 (2), 121-134. https://doi.org/10.1080/19012276.2014.926227

Brinkmann, S. \& Petersen, A. (2015). Diagnoser: Perspektiver, kritik og diskussion. I: Diagnoser, S. Brinkmann \& A. Petersen (red.). Aarhus: Klim, s. 341-360.

Christoffersen, M.N. \& Hammen, I. (2011). ADHD-indsatser: en forskningsoversigt, København: SFI - Det Nationale Forskningscenter for Velfærd.

Conrad, P. (2007). The medicalization of society. Baltimore, MD: Johns Hopkins University Press.

Conrad, P (1975). The discovery of hyperkinesis: Notes on the medicalization of deviant behavior, Social Problems, vol. 23 (1), 12-21. https://doi.org/10.2307/799624

Cooper, P. (2008). Like alligators bobbing for poodles? A critical discussion of education, ADHD and the biopsychosocial perspective. Journal of Philosophy of Education, 42(3-4), 457-74. https://doi.org/10.1111/j.1467-9752.2008.00657.x

Dalsgaard, S. (2002). Long Term Psychiatric and Criminality Outcome of Children with Attention-Deficit/ Hyperactivity Disorder, Ph.d.-afhandling, Aarhus: Det Sundhedsvidenskabelige Fakultet, Aarhus Universitet.

Ege, P. (2004). Stofmisbrug og afhængighed hos unge og voksne. København: Hans Reitzels Forlag

Ekeland, Tor-Johan (2014). Psykiatridiagnosar - ein kunnskapskritikk. Tidsskrift for Norsk Psykologforening, vol. 51(9), 715-722.

Flensborg-Madsen, T. Mortensen, E. L. Knop, Joachim, Becker, U. Sher, L. \& Grøn-bæk, M (2009). Comorbidity and temporal ordering of alcohol use disorders and other psychiatric disorders: results from a Danish registerbased study. Comprehensive Psychiatry, 50(4), 307-314. https://doi.org/10.1016/j.comppsych.2008.09.003

Frederiksen, K. (2009). 'Projekt Bedre Udredning' hjælper sindslidende misbrugere på rette kurs. Stof, 14, 60-63.

Gordon, J. A., Diehl, R. L., \& Anderson, L. (2012). Does ADHD Matter? Examining Attention Deficit and Hyperactivity Disorder on the Likelihood of Recidivism Among Detained Youth. Journal of offender rehabilitation, 51(8), 497-518.

https://doi.org/10.1080/10509674.2012.702714 
Grant, B. F. Stinson, F. S. Dawson, D. A. Chou, S. P. Dufour M. C. \& Compton, W. (2004) Prevalence and co-occurrence of substance use disorders and independent mood and anxiety disorders: Results from the National Epidemiological Survey on Alcohol and Related Conditions. Archives of General Psychiatry, 61(8), 807-816.

https://doi.org/10.1001/archpsyc.61.8.807

Gregg, L. Barrowclough, C. \& Haddock, G. (2007). Reason for Increased Substance Use in Psychosis. Clinical Psychological Review, vol. 27(4), 494-510. https://doi.org/10.1016/j.cpr.2006.09.004

Guldager, S. \& Hesse, M. (2012) Basisscreening for psykiske lidelser i misbrugsbehandlingen. København: KL (www.kl.dk/klscreener).

Järvinen, M. (1998), Det dårlige selskab. Misbrug, behandling og omsorg, Soc. Pol., Holte. Johansen, B.S. \& Johansen, K.S. (2014). Heroin: From Drug to Ambivalent Medicine. On the Introduction of Medically Prescribed Heroin and the Emergence of a New Space for Treatment. Culture, Medicine and Psychiatry, https://doi.org/10.1007/s11013-014-9406-7

Johansen, K.S. (2015). 'Det er ikke en forlystelsespark, vi driver her'. Behandling vs. nydelse og andre modsætninger i det danske program for lægeordineret heroin. Tidsskriftet Antroplogi, 71, 33-50.

Johansen, K.S. (2013). Heroinbehandling i Danmark - en undersøgelse af brugere og be handling. Glostrup: KABS VIDEN.

Johansen, K.S. (2009). Dobbelt diagnose - Dobbelt behandling. Glostrup: KABS VIDEN. Jutel, A.G. (2011). Putting a Name to It: Diagnosis in Contemporary Society. Baltimore: The Johns Hopkins University Press.

Jørgensen, C.R. (2014). ADHD. Bidrag til en kritisk psykologisk forståelse, Hans Reitzels Forlag, København.

Keane, H. (2008). Foucault on methadone: Beyond biopower. International Journal of Drug Policy, 20, 450-452 https://doi.org/10.1016/j.drugpo.2008.10.005

Kleinman, A. (1988). Rethinking psychiatry. Form cultural category to personal experience. New York: The Free Press.

Kooij, S.J., Bejerot, S., Blackwell, A., et al. (2010). European consensus statement on diagnosis and treatment of adult ADHD: The European Network Adult ADHD, BMC psychiatry, 10, 67. https://doi.org/10.1186/1471-244X-10-67

Kyvsgaard, B. (1989). - og fængslet ta'r de sidste: om kriminalitet, straf og levevilkår. København: Jurist- og Økonomforbundets Forlag.

Lamont, M. \& Molnár, V. (2002). The study of boundaries in social sciences, Annual Review of Sociology, 28: 167-195. https://doi.org/10.1146/annurev.soc.28.110601.141107

Maggs, J. L., Patrick, M. E., \& Feinstein, L. (2008). Childhood and adolescent predictors of alcohol use and problems in adolescence and adulthood in the National Child Development Study, Addiction, 103, 7-22. https://doi.org/10.1111/j.1360-0443.2008.02173.x

Moncrieff, J., \& Timimi, S. (2011). Critical analysis of the concept of adult attention-deficit hyperactivity disorder. The Psychiatrist, 35(9), 334-338. 
https://doi.org/10.1192/pb.bp.110.033423

Mueser, K. T. Noordsy, D. L. Drake, R. \& Fox, L. (2003). Integrated Treatment for Dual Disorders. A Guide to Effective Practice. New York: The Fuilford Press.

Møller, J.R. \& Johansen, K.S. (Kommende). Spændingsfeltet mellem dynamik og stabilitet. En antropologisk analyse af arbejdet med udvikling og behandling af mennesker med sindslidelser i det danske velfærdssamfund, Tidsskriftet Antropologi, nr. 72.

Nielsen, Klaus (2012). Alle Drenge Har Det - kritiske overvejelser over ADHDdiagnosen. Gjallerhorn, 15, 31-38.

Pedersen, W. (2015). From badness to illness: Medical cannabis and selfdiagnosed attention deficit hyperactivity disorder. Addiction Research $\mathcal{E}$ Theory, 23(3), 177-186. https://doi.org/10.3109/16066359.2014.954556

Petersen, Anders (2015). Omkring Diagnosekulturen: Depression som seismograf for samtiden. Dansk Sociologi, 25(1), 8-25.

Poulsen, H.D., Gottlieb, P. \& Adserballe, H. (2000). Ret og tvang i psykiatrien. København: Munksgaard.

Psykiatrifonden (2007). ADHD. Opmærksomhedssygdomme hos børn og voksne. København: Psykiatrifondens Forlag.

Prosser, B., \& Reid, R. (2013). The DSM-5 changes and ADHD: More than a tweak of terms. Australian and New Zealand Journal of Psychiatry, 47(12), 1196-1197. https://doi.org/10.1177/0004867413509695

Prosser, B. (2014). Attention deficit hyperactivity disorder in Australia: Perspectives from the sociology of deviance, Journal of Sociology.

Rasmussen, P.S. \& Johansen, K.S. (2013). Oplevet diskrimination og stigmatisering blandt mennesker med psykisk sygdom. København: KORA.

Rose, N. (2007). The politics of life itself: Biomedicine, power, and subjectivity in the twenty-first century. Princeton, N.J. Princeton University Press. https://doi.org/10.1515/9781400827503

Rose, N. (2010). »Screen and intervene«: governing risky brains, History of the Human Sciences, 23(1), 79-105. https://doi.org/10.1177/0952695109352415

Rose, N., \& Abi-Rached, J. M. (2013). Neuro: The new brain sciences and the management of the mind. Princeton, N.J. Princeton University Press. https://doi.org/10.1515/9781400846337

Socialstyrelsen (2013). Validerede instrumenter til evalueringer på det sociale område. København: Socialstyrelsen.

Sundhedstyrelsen (2015). National klinisk retningslinje For udredning og behandling af ADHD hos voksne - med forstyrrelse af aktivitet og opmærksomhed samt opmærksom-hedsforstyrrelse uden hyperaktivitet. København, Sundhedsstyrelsen.

Toftdahl, N. G. Nordentoft, M. \& Hjorthøj C. (2015) Prevalence of substance use disorders in psychiatric patients: a nationwide Danish population-based study. Social psychiatry \& Psychiatric Epidemiology, https://doi.org/10.1007/s00127-015-1104-4

Vehmas, Simo (2011). Disability and moral responsibility. TRAMES, 15(65/60), 2, 156-167. 
https://doi.org/10.3176/tr.2011.2.04

Visser, J. \& Jehan, Z. (2009). ADHD: A scientific fact or a factual opinion? A critique of the veracity of Attention Deficit Hyperactivity Disorder. Emotional and Behavioural Difficulties 14( 2), 127-40. https://doi.org/10.1080/13632750902921930

Wilens, T.E. (2006). Attention Deficit Hyperactivity Disorder and Substance Use Disorders. The American Journal of Psychiatry, 163(12), 2059-2063. https://doi.org/10.1176/ajp.2006.163.12.2059

Willig, Ø. \& Østergaard, M. (2005). Sociale Patologier. København: Hans Reitzels Forlag.

WHO (1994). ICD-10. Psykiske lidelser og adfærdsmæssige forstyrrelser. København: Munksgaard Danmark.

Young, S.J., Adamou, M., Bolea, B., Gudjonsson, G., et al. (2011).

The identification and management of ADHD offenders within the criminal justice system: A consensus statement from the UK adult ADHD network and criminal justice agencies, BMC Psychiatry, vol. 11, no. 1.

https://doi.org/10.1186/1471-244x-11-32 